\title{
An Analysis Of SAS No. 99 And Its Impact On The Big Fraud In Kentucky
}

Thomas G. Noland, (Email: tgnoland@georgiasouthern.edu), Georgia Southern University Kenneth M. Washer, Texas A\&M Commerce

\begin{abstract}
Statement on Auditing Standards (SAS) No. 99 was implemented in 2002 and requires auditors to expand audit procedures to detect fraud. This paper analyzes the impact the procedures outlined in SAS No. 99 would have made if they had been in effect at the time of one of the largest frauds in the history of Kentucky. Wallace Wilkinson, former governor of Kentucky, was the target of FBI investigations at least seven times. Wilkinson entangled such well-known names as the late Dave Thomas, founder of Wendy's restaurants, in his fraud. At the time of his death in July 2002, Wilkinson's business empire was in bankruptcy after being kept afloat for years by one of the largest Ponzi schemes in the history of the state.
\end{abstract}

\section{STATEMENT ON AUDITING STANDARDS (SAS) NO. 99}

AS No. 99 requires auditors to discuss the potential for material misstatements in financial statements in a "brainstorming" session prior to beginning the audit. The goal of brainstorming is to identify ideas on how fraud may occur and be concealed by the entity being audited. This session requires auditors "to think like a crook" and determine ways in which funds could be embezzled or financial statements could be manipulated.

The auditor is required to make inquiries of the audit committee, internal audit personnel and other personnel about the possibility or suspicion of fraud. Other personnel should include individuals outside normal accounting channels. Asking personnel outside of the accounting function about the possibility of fraud allows auditors to gain an understanding necessary to plan an effective audit.

SAS No. 99 adds two new requirements to the risk assessment process. The first requirement is to always assume that improper revenue recognition is a fraud risk. Many financial reporting frauds are a result of improper revenue recognition. Revenue recognition schemes come in several forms with the first being recognizing revenue in the wrong period by holding the books open past the end of the accounting period. Another scheme is the bill and hold transaction. The company goes ahead and bills the customer for merchandise but retains the goods in its inventory. A common problem here is that the customer never ordered the goods and has no intention of ordering them until the next period. Another revenue recognition fraud is channel stuffing. Channel stuffing involves shipping merchandise to customers at deep discounts and allowing these customers to return this merchandise if they are not able to sell it.

The other new requirement in the risk assessment process is to always identify the risk of management override as a fraud risk. Management override has been a common occurrence in many of the high profile recent frauds such as Enron and WorldCom. Top executives had the ability to change the accounting numbers in order to meet earnings expectations prior to the release of year-end and quarterly financial statements.

The auditor must test journal entries for proper support and pay particular attention to any unusual entries at the end of the quarter or year-end. The auditor must also review accounting estimates and determine if the underlying assumptions are valid. Estimates such as an assets useful life, the allowance for doubtful accounts, 
pension liability, warranty liability and inventory valuation are all subject to manipulation by management override and must be carefully examined.

Perhaps the biggest emphasis of SAS No. 99 is that of professional skepticism. The auditor cannot rely on client representations but must gather supporting evidence to substantiate the client's assertions. The auditor must set aside any past relationship and not assume all clients are honest. Auditors must adopt a more skeptical mind-set and evaluate the audit evidence accordingly.

\section{THE ENTREPRENEUR}

Wallace Wilkinson came from humble beginnings. He was the son of a small-town grocer who dropped out of the University of Kentucky to open a bookstore in Lexington, Kentucky in 1962. Because of his dropout status, Wilkinson was unable to secure financing from banks and borrowed money from friends to begin operations. Wilkinson built his own shelves, worked long hours, and depended financially on the $\$ 115$ a week his wife Martha took home from her job at Greyhound Bus lines. (Cheves July 22, 2001)

Every spare penny Wilkinson made went back into the business. Through slow and steady growth, Wilkinson grew Wallace's Bookstores from the one original bookstore to an empire that operated 92 branches on 60 college campuses in 25 states. Over time, Wilkinson diversified his interests into banking, real estate, and farming.

Wilkinson first surfaced on the general public's radar screen in 1981 when he wanted to build a 50 -story World Coal Center in downtown Lexington, Kentucky. Wilkinson stated his building would house the offices of major coal companies and make Lexington the center of international coal. After purchasing and demolishing a historic hotel, Wilkinson had to change his plans. The coal market dried up and Wilkinson had to delay his building. The big hole in downtown Lexington came to be known as "Wally's Folly."

Wilkinson, however, was able to secure a unique financing package that included help from the state and Lexington-Fayette County Government and built a 21-story apartment plaza. This site was often praised as a model for downtown renewal and revitalization.

\section{THE POLITICIAN}

In 1987, Wilkinson, with the help of a relatively unknown political consultant named James Carville, (Carville later masterminded the election of Bill Clinton to the White House) was elected Governor of Kentucky. Wilkinson put $\$ 2.3$ million of his own money into the campaign and rode the campaign theme of a state lottery to fund education to victory. Wilkinson used lottery money and other tax increases to fund education reform in the Commonwealth. While in office, Wilkinson tried to change Kentucky's constitution that prohibited governors from serving more than one consecutive term. When this attempt failed, his wife Martha ran for governor but her campaign failed to gain traction with the voters.

Wilkinson's tenure as Governor was stormy. His nephew, Bruce Wilkinson, who served as appointment's director, was convicted of conspiracy to commit extortion and sentenced to three years in prison. Wilkinson's biggest controversy during office was his sale of the Capital Plaza Hotel in Frankfort for an inflated price. Wilkinson sold the hotel to a state regulated company, Kentucky Central Life Insurance. Kentucky Central was later declared insolvent and taken over by insurance regulators. Wilkinson was sued by insurance regulators and after several years of litigation forced to pay an \$11 million settlement. One of Wilkinson's final acts as Governor was to appoint himself to an unprecedented six-year term on the University of Kentucky Board of Trustees. Wilkinson's action caused such a public uproar that his successor, Governor Brereton Jones, used newly enacted legislation to remove Wilkinson and some of his appointees from university boards. 


\section{THE FRAUDSTER}

No one is exactly sure when Wilkinson became financially insolvent and began his Ponzi scheme. Some speculate that Wilkinson was broke for years before being elected Governor but managed to hide it. Others state that the source of his financial difficulty was the expansion of his bookstore chain. A few hypothesize that his campus bookstores were unprofitable because he overpaid universities for the right to manage their campus bookstores. When Wilkinson was first forced into involuntary Chapter 11 bankruptcy in February 2001, he stated that his financial difficulties were due to losses associated with the Internet start-up ecampus.com. Wilkinson along with such notables as Wendy's founder, Dave Thomas, Long John Silver's founder, James Patterson, and former Maryland and Ohio State University President, William Kirwan, were key investors in the on-line bookstore that began operations in 1999. While ecampus.com and Wallace's declared bankruptcy after Wilkinson was forced into involuntary bankruptcy, it is now clear that Wilkinson had been broke at least since 1992 .

According to documents filed in U.S. Bankruptcy court, Wilkinson had paid no federal income taxes since 1991 and had reported losses ranging from \$2.5 million to \$32.5 million each year between 1992 and 1999 . The forensic accounting firm of Jay Alix \& Associates of Chicago determined that more than $\$ 2.8$ billion dollars flowed through Wilkinson's bank accounts from 1992 until the time he was forced into bankruptcy. In 2000, Wilkinson reported $\$ 3$ million in salary, interest and dividends but reported business losses and interest payments of $\$ 52.7$ million on his tax returns. (Jordan August 4, 2001)

Wilkinson's empire was built on a mountain of debt. Wallace's would borrow money as a corporation and then lend money to Wilkinson. Wilkinson would borrow money from banks and individuals, payback the interest and some of his creditors and then borrow some more. In a May 2001, interview, Wilkinson acknowledged that he paid interest expense on notes to individual creditors with borrowings from other creditors.

Wilkinson's bankruptcy filing revealed he had debts of $\$ 418.4$ million and assets of only $\$ 86.8$ million. Wilkinson owed $\$ 120$ million to three financial institutions whose claims were secured by stock in Wallace's Bookstores and ecampus.com. The remaining \$298 million was in unsecured debt. Wilkinson owed Wallace's bookstores some $\$ 50.7$ million at the time of the bankruptcy filing. (Jordan March 15, 2001)

Wilkinson's major assets other than his bookstore and Internet business were various real property holdings worth $\$ 7$ million to include a home in Naples, Florida ( $\$ 1.9$ million) and a home in Lexington, Kentucky $(\$ 886,000)$. Other significant assets were a yacht and boat valued at $\$ 1.65$ million and $\$ 500,000$ respectively. Wilkinson also reported receivables from his two children valued at approximately $\$ 2.5$ million. A partial listing of assets and liabilities is listed in Table I.

Jay Alix \& Associates stated that Wilkinson was operating a Ponzi scheme by using new loans to repay old loans while giving the impression that the loans were being repaid from Wallace's profits. Alix stated that there was no explanation other than the operation of a Ponzi scheme, for the magnitude, timing and volume of transfers. In the year prior to bankruptcy, Wilkinson and Wallace's transferred nearly $\$ 800$ million even thought total assets of Wallace's were approximately $\$ 135$ million when Wallace's filed bankruptcy in April 2001. The accounting firm of J.H. Cohn stated that Wallace's had overstated net income by some $\$ 73$ million for the four years that ended March 31 , 2000. Instead of profits of $\$ 25.2$ million, Wallace's actually had losses of $\$ 47.8$ million. (Jordan June 28,2002 )

In the year before his bankruptcy, Wilkinson borrowed some $\$ 457$ million primarily to repay old loans and interest. Wilkinson paid over $\$ 50$ million in interest payments in 1999. Interest payments were extreme due to the high credit risk Wilkinson posed. Having already pledged most of his assets, Wilkinson had to resort to borrowing money at unsecured rates as high as $20 \%$.

Dave Thomas, founder of Wendy’s lent Wilkinson \$25.5 million in unsecured funds. He also personally guaranteed another promissory note for $\$ 25$ million. Thomas had invested at least $\$ 5$ million in ecampus.com and another \$10 million in Wallaces's Bookstores. After Wilkinson's bankruptcy, Thomas was sued over the \$25 
million loan guaranty and by other ecampus.com investors. Six days before his death in 2002, Thomas reached an out of court settlement over the $\$ 25$ million loan guaranty. (Jordan January 9, 2002)

\section{THE AFTERMATH}

In June 2001, Wilkinson was forced to testify before the U.S. Bankruptcy court. Prior to his questioning, his attorney, Gregory Haynes, stated that Wilkinson would invoke his Fifth Amendment privilege against selfincrimination. At his deposition, he invoked his Fifth Amendment privilege more than 140 times. Wilkinson's attorney stated he was concerned about possible federal investigations by the Justice Department and the Securities and Exchange Commission. Wilkinson's attorney stated that the decision to take the Fifth was decided in part after consulting with prominent defense attorney and Watergate prosecutor, James Neal, of the Nashville, Tennessee law firm of Neal \& Harwell. Both the SEC and the Justice Department confirmed that they were conducting probes into Wilkinson's financial dealings.

In June 2001, Wallace's Bookstores was liquidated for a little over \$31 million. In July 2001, ecampus.com was sold for just over \$2.5 million dollars to Book Acquisition even though it had ran through \$118 million dollars since its inception in 1999. Wilkinson's largest individual creditor, George Valassis of Deerfield, Michigan is the controlling shareholder of Book Acquisition. (Lexington Herald-Leader July 19, 2001)

In July 2002, Wallace Wilkinson passed away from a massive stroke after suffering from cancer and heart disease. In December 2002, a settlement was approved in the bankruptcy case against Wilkinson. Wilkinson's sons were forced to turn over about $\$ 2$ million from the sale of their Lexington homes to satisfy loans made to them by their father. His wife Martha managed to come out of the bankruptcy with the Naples, FL home valued at $\$ 1.9$ million, \$250,000 in cash, household goods valued at \$66,000, and a 2000 Mercury Mountaineer valued at \$16,000. (Jordan December 3, 2002)

In June 2003, Potter \& Co. LLP, a Kentucky based accounting firm founded in 1918, reached and undisclosed settlement over litigation concerning their audit of Wallace's. The United Company, the estate of the late Dave Thomas, George Valassis, and Union Planters Bank, filed the lawsuits. The lawsuits had accused Potter \& Co. of negligence in auditing Wallace's Bookstores and that this negligence contributed to Wallace's collapse. Potter \& Co. failed to detect that Wallace's actually suffered losses of over $\$ 47$ million in the four years ending March 31, 2000. Wallace's had reported profits of some $\$ 25$ million during that time frame. Potter \& Co. apparently did not fully assess Wilkinson's creditworthiness as he owed Wallace's over $\$ 50$ million.

\section{THE QUESTIONS}

If SAS No. 99 had been implemented prior to 2002 would this have made a difference in the audit of Wallace's? Another question is how could Wilkinson fool so many prominent corporations and people? How could he convince them to lend him so much money unsecured? What role did the "failed" audit of Wallace's play in this ponzi scheme? Did Wilkinson hide his true financial position from the auditor's or was it not investigated?

SAS No. 99 requires the auditors to have an attitude of professional skepticism. Wilkinson's fame and perceived "midas" touch may have prevented the auditors from fully exploring possible accounting irregularities. Related party transactions should always be an area of concern for an auditor, but the transactions between Wallace's and Wilkinson were not subject to enough scrutiny to determine that a fraud existed. Wilkinson and his sons had total control over Wallace's and therefore could easily transfer money between the corporate entity and their personal accounts. Would the brainstorming session required by SAS No. 99 have discussed the possibilities of related party transactions and management override between the corporation and Wilkinson personally? SAS No. 99 also requires auditors to ask questions about possible fraud from individuals outside the accounting area. If these questions had been asked of other personnel what information may have been detected?

Both management override and revenue recognition were potential areas of concern for Wallace's auditors. Wallace's could have engaged in both channel stuffing and bill and hold transactions with regards to inventory. 
Wilkinson or his sons could have also easily manipulated the financials to ensure that they were in agreement with all debt covenants. It appears that Wilkinson was engaged in revenue manipulation since Wallace's reported profits of \$25 million over four years when losses of \$47 million actually occurred. It is also clear that Wallace's showed a large loan to Wilkinson as an individual. Why was Wilkinson's true financial position not investigated since he owed over $\$ 50$ million to Wallace's. Looking closely at the estimate of doubtful accounts is also part of the requirements of SAS No. 99. Wallace's loan to Wilkinson obviously should have been evaluated more thoroughly.

Besides Wilkinson and his accountants, perhaps the biggest people at fault were the bankers. They in many cases recognized Wilkinson as a substantial credit risk because of the high interest rates they charged (in some cases 20\%). Did Wilkinson's financial statements provided to the bank show his true financial position? Did the banker's analyze his tax returns? Did Wilkinson commit bank fraud by not giving accurate financial statements? These questions remain unanswered.

In closing, it is virtually impossible to know what really happened with Wilkinson's financial holdings. The FBI began investigating him in 1984 (as shown in Table II) but the financial trail begins only after he left the governor's mansion when losses began to appear on his tax returns. However, it does appear that the accounting firm, Potter \& Co., did not exercise the degree of professional skepticism that was needed to detect the fraud. While SAS No. 99's implementation would not have guaranteed the detection of fraud, the required brainstorming, coupled with increased professional skepticism and recognition of possible revenue recognition issues and management override would have made it more likely. SAS No. 99 aside, the question that may never be answered is the one often asked. When did Wilkinson go broke or was he always insolvent?

TABLE I

PARTIAL LISTING OF ASSETS AND LIABILITIES

\begin{tabular}{|c|c|c|c|}
\hline ASSETS & & LIABILITIES & \\
\hline $\begin{array}{l}\text { Stock in Private Companies } \\
\text { Wallace's Bookstore } \\
\text { ecampus.com } \\
\text { Park Plaza Associates } \\
\text { Wilkinson Group } \\
\text { Wilkinson Flying Service }\end{array}$ & $\$ 58$ million & $\begin{array}{l}\text { Secured Debt } \\
\text { United Co. } \\
\text { Union Planter's Bank } \\
\text { Wells Fargo Bank }\end{array}$ & $\$ 120.6$ million \\
\hline Wilkinson Farms & $\$ 3.25$ million & $\begin{array}{l}\text { George Valassis } \\
\text { (Founder of Nationally Known } \\
\text { Marketing Firm) }\end{array}$ & \$77 million \\
\hline Residence - Naples, FL & $\$ 1.93$ million & Wallace's Bookstores & $\$ 50.7$ million \\
\hline Home - Lexington, KY & $\$ 886,000$ & $\begin{array}{l}\text { L.D. Gorman \& Affiliated } \\
\text { Companies } \\
\text { (Banker and Coal Magnate) }\end{array}$ & $\$ 41.5$ million \\
\hline 1998 Pershing Yacht & $\$ 1.65$ million & $\begin{array}{l}\text { Dave Thomas } \\
\text { (Founder of Wendy's Restaurants) }\end{array}$ & $\$ 25.5$ million \\
\hline Cash & $\$ 811,000$ & $\begin{array}{l}\text { Milo Bryant } \\
\text { (Former Kentucky Transportation } \\
\text { Secretary) }\end{array}$ & $\$ 12.1$ million \\
\hline 1994 Sea Ray Boat & $\$ 500,000$ & $\begin{array}{l}\text { Martin McInerney } \\
\text { (Car Dealer Detroit, Michigan) }\end{array}$ & $\$ 8$ million \\
\hline Boat Slip-Florida & $\$ 190,000$ & $\begin{array}{l}\text { James Patterson } \\
\text { (Founder of Long John Silvers) }\end{array}$ & $\$ 5.5$ million \\
\hline Mercedes Automobiles & $\$ 144,000$ & $\begin{array}{l}\text { Leonard Lawson } \\
\text { (Businessman and Road } \\
\text { Contractor) }\end{array}$ & $\$ 5$ million \\
\hline Kentucky Derby Box & $\$ 9,240$ & $\begin{array}{l}\text { Autry Qualified Trust (Estate of } \\
\text { Late actor Gene Autry) }\end{array}$ & $\$ 3$ million \\
\hline
\end{tabular}


1962 - Wilkinson starts first bookstore

1981 - Attempts to build World Coal Center

1984 - First of seven FBI probes

1987 - Elected Governor of Kentucky

1999 - Starts ecampus.com

2001 - Forced into Chapter 11 Bankruptcy

2002 - Wilkinson dies from cancer and heart disease

2002 - Bankruptcy settlement approved

2003 - Potter \& Co. LLP reach settlement over negligent audit

\section{REFERENCES}

1. Cheves, J., 2001. Wilkinson Crisis has wealthy friend scrambling for cash. Coal Magnate L.D. Gorman finds his business empire threatened. Lexington Herald-Leader (July 7).

2. Cheves, J., 2001. As his star brightened, his caution faded once-thrifty Wilkinson wound up blowing his millions. Lexington Herald-Leader (July 22).

3. Cincinnati Enquirer, 2001. Creditors question Wilkinson about bankruptcy. (March 18).

4. Courier-Journal, 2002. Judge lets Wilkinson company sue accounting firm. (July 5).

5. Jordan, J., 2001. Wilkinson details his debts, assets filing lists at least $\$ 418.4$ million owed. Lexington Herald-Leader (March 15).

6. Jordan, J., 2001. Transfers to Wilkinson: \$405 million company lists funds that went to Ex-Governor in 12 months before bankruptcy. Lexington Herald-Leader (April 5).

7. Jordan, J., 2001. Wilkinson has paid no U.S. Taxes Since 1991 attorney cites business strategy. Lexington Herald-Leader (August 4).

8. Jordan, J., 2001. Ex-friends say Wilkinson got loans by fraud. Lexington Herald-Leader (December 29).

9. Jordan, J., 2002. Friendship with Wilkinson proved costly for Thomas. Lexington Herald-Leader (January 9).

10. Jordan, J., 2002. Report: Ponzi scheme kept Wilkinson afloat. Lexington Herald-Leader (June 28).

11. Jordan, J., 2002. Wilkinson Settlement Approved. Lexington Herald-Leader

12. (December 3).

13. Jordan, J., Brammer, J., Estep, B., 2002. Former Governor, Businessman Dies. Lexington Herald-Leader (July 6).

14. Kentucky Post. 2001. Ex-gov mum, fears feds. (July 5).

15. Lexington Herald-Leader. 2001. Ecampus investors sue Wendy's Founder. (June 26).

16. Lexington Herald-Leader. 2001. Shareholder takes control of ecampus. (July 19).

17. Lexington Herald-Leader. 2002. New fraud charges leveled at Wilkinson. (February 27).

18. Lexington Herald-Leader. 2002. Bank sues Wilkinson accountants. (May 10).

19. Lexington Herald-Leader. 2002. Potter lawsuits are consolidated. (July 9).

20. Lexington Herald-Leader. 2003. FBI Investigated Wilkinson Seven Times. (May 9).

21. Lexington Herald-Leader. 2003. Potter-Wallace's Settlement OK'D. (June 25). 